\title{
N-Alkylation Reaction in the Synthesis of Tetra-Substituted Glycoluryls
}

\author{
Anastasia A. Sinitsyna* and Sergey G. Il'yasov \\ Institute for Problems of Chemical \\ and Energetic Technologies SB RAS \\ Biysk, Russian Federation
}

Received 20.12.2019, received in revised form 16.01.2020, accepted 03.02.2020

\begin{abstract}
A new method is suggested herein for the synthesis of tetrasubstituted glycolurils by treatment of disubstituted glycolurils (di-tert-butylglycolurils, di-isopropylglycoluril) with alkylating agents such as methyl iodide, ethyl bromide and benzyl chloride in acetonitrile in the presence of $\mathrm{KOH}$. Optimum conditions for the preparation of the target product in high yield were studied by the example of the synthesis of dibenzyl-di-tert-butylglycoluril: time $3 \mathrm{~h}$ and reaction temperature $75^{\circ} \mathrm{C}$ at a $1: 4$ $\mathrm{M} / \mathrm{M}$ molar ratio of disubstituted glycoluril to benzyl chloride. Thus, the target product yield was $83 \%$. It was also found that benzyl chloride should be used as the alkylating agent because the product yield under the same equal conditions was higher with benzyl chloride than with benzyl bromide which in turn is more toxic and less available.
\end{abstract}

Keywords: ureas, glycoluryls, disubstituted glycoluryls, N-alkylation, heterocycles.

Citation: Sinitsyna A.A., Il'yasov S.G. N-alkylation reaction in the synthesis of tetra-substituted glycoluryls, J. Sib. Fed. Univ. Chem., 2020, 13(1), 40-45. DOI: 10.17516/1998-2836-0164

(C) Siberian Federal University. All rights reserved

This work is licensed under a Creative Commons Attribution-NonCommercial 4.0 International License (CC BY-NC 4.0).

* Corresponding author E-mail address: nastya.sinitsyna.1994@mail.ru 


\title{
Реакция N-алкилирования \\ в синтезе тетразамещенных гликольурилов
}

\author{
А.А. Синицына, С.Г. Ильясов \\ Институт проблем химико-энергетических технологий СО РАН \\ Российская Федерация, Бийск
}

\begin{abstract}
Аннотация. Предложен новый способ получения тетразамещенных гликольурилов, заключающийся в обработке дизамещенных гликольурилов (дитрет-бутилгликольурила, диизопропилгликольурила) алкилирующими агентами: йодистый метил, бромистый этил и хлористый бензил в среде ацетонитрила в присутствии основания КОН. На примере получения дибензил-дитрет-бутилгликольурила изучены оптимальные условия для получения продукта с высоким выходом: продолжительность 3 ч и температура реакции $75{ }^{\circ} \mathrm{C}$ при мольном соотношении дизамещенного гликольурила к бензил хлориду 1:4 моль/моль. Таким образом, выход целевого продукта составил 83 \%. Также установлено, что в качестве алкилирующего агента следует использовать хлористый бензил в связи с тем, что выход продукта в одних и тех же условиях выше, чем при использовании бромистого бензила, который, в свою очередь, является наиболее токсичным и менее доступным.
\end{abstract}

Ключевые слова: мочевины, гликольурилы, дизамещенные гликольурилы, $\mathrm{N}$-алкилирование, гетероциклы.

Цитирование: Синицына, А.А. Реакция N-алкилирования в синтезе тетразамещенных гликольурилов / А.А. Синицына, С.Г. Ильясов // Журн. Сиб. федер. ун-та. Химия, 2020. 13(1). С. 40-45. DOI: 10.17516/1998-2836-0164

$\mathrm{N}$-alkyl-substituted 2,4,6,8-tetraazabicyclo[3.3.0]octane-3,7-diones (glycolurils) are known to exhibit a broad spectrum of biological activity. In particular, 2,4,6,8-tetramethylglycoluril (Mebicar) and 2,6-diethyl-4,8-dimethylglycoluril (Albicar) are compounds having anxiolytic properties [1-3].

Thus, synthesis of new N-alkyl-substituted glycolurils or improvement in the well-known synthetic methods is permanently receiving interest among researchers.

The chemical structure of glycoluril represents an extremely attractive object for further targeted modification because glycoluril comprises four active nucleophilic sites through which substitution reactions may take place $[4,5]$.

The literature $[6,7]$ describes a method for preparing 2,6-dimethyl-4,8-di-tert-butylglycoluril via cyclocondensation of 1-methyl-3-tert-butylurea with glyoxal, in which case a racemic mixture is formed that consists of the three compounds: cis- and trans-isomers of dimethyl-di-tertbutylglycoluril and hydantoin. With that, the yield of trans-isomers was found to be threefold that of cis-isomers [8].

Glycoluril tetraderivatives can be not only bioactive but also highly energetic. Tetranitroglycoluril (SORGUIL) is produced by nitration of glycoluril through the formation of dinitroglycoluril (DINGU) $[9,10]$. 
The present paper reports the results on the synthesis of tetrasubstituted glycolurils by the $\mathrm{N}$-alkylation reaction in order to expand the series of tetrasubstituted glycolurils and examine their presumed biological activity in the PASS program.

\section{Experimental}

The work was performed with instruments of the Biysk Regional Center for Shared Use of Scientific Equipment of the SB RAS (IPCET SB RAS, Biysk).

Infrared spectra were recorded in $\mathrm{KBr}$ pellets on a FT-801 FTIR spectrometer under conditions of disturbed total internal reflection.

NMR spectra were taken on a Bruker Avance III 500 spectrometer operated at $400.13 \mathrm{MHz}$ for ${ }^{1} \mathrm{H}$ and at $100.61 \mathrm{MHz}$ for ${ }^{13} \mathrm{C}$. The spectra were acquired from the solution in $\mathrm{CD}_{3} \mathrm{CN}$.

General synthesis of di-tert-benzylglycoluril: To acetonitrile $(20 \mathrm{~mL})$ was added disubstituted glycoluril $(0.0025 \mathrm{M})$, alkylating agent $(0.01 \mathrm{M})$ (methyl iodide, ethyl bromide or benzyl chloride) and $\mathrm{KOH}(0.01 \mathrm{M})$. The reaction mass was heated to $75^{\circ} \mathrm{C}$ and held for $3 \mathrm{~h}$. Afterwards, the precipitated KHal salt was discarded and the solvent was withdrawn from the mother solution. The resulting solid residue was washed with diethyl ether and then with water to dissolve the residual salt, and then with diethyl ether again. The resultant powder was collected by filtration and dried under atmospheric pressure.

3a. 2,6-Dimethyl-4,8-di-tert-butyl-2,4,6,8-tetraaza[3.3.0]octane-2,7-dione: Yield $40 \%$. $\mathrm{Mp}=144-146{ }^{\circ} \mathrm{C} . \mathbf{I R}, \mathrm{cm}^{-1}: 2984,2971,2910,2887,1711,1690 .{ }^{1} \mathbf{H}$ NMR (400 MHz, CD $\left.\mathrm{CN}\right) 5,17$ (s, $2 \mathrm{H}, \mathrm{N}-\mathrm{CH}-\mathrm{N}), 2,80\left(\mathrm{~s}, 6 \mathrm{H}, \mathrm{CH}_{3}\right), 1,44\left(\mathrm{~s}, 18 \mathrm{H}, \mathrm{C}\left(\underline{\mathrm{CH}}_{3}\right)_{3} .{ }^{13} \mathrm{C} \mathbf{N M R}\left(100 \mathrm{MHz}, \mathrm{CD}_{3} \mathrm{CN}\right) \delta 158.87(\mathrm{C}=\mathrm{O})\right.$, $69.94(\mathrm{~N}-\mathrm{CH}-\mathrm{N}), 53.51\left(\underline{\mathrm{C}}\left(\mathrm{CH}_{3}\right)\right), 28.34\left(\mathrm{CH}_{3}\right)$.

3b. 2,6-Diethyl-4,8-di-tert-butyl-2,4,6,8-tetraaza[3.3.0]octane-2,7-dione: Yield: $59 \%$. $\mathrm{Mp}=122-124{ }^{\circ} \mathrm{C} . \mathbf{I R}, \mathrm{cm}^{-1}: 3445,3340,3222,2973,2933,2875,1686,1655 .{ }^{1} \mathbf{H}$ NMR $(400 \mathrm{MHz}$, $\mathrm{CD}_{3} \mathrm{CN}$ ) 5.28 (s, 2H, N-CH-N), 3.17-3.23 (q, 4H, $\mathrm{CH}_{2}$ ), 1.27 (s, 18H, $\left.\mathrm{CH}_{3}\right), 1.02-1.05$ (t, $6 \mathrm{H}, \mathrm{CH}, \mathrm{CH}_{3}$ ). ${ }^{13} \mathrm{C}$ NMR $\left(100 \mathrm{MHz}, \mathrm{CD}_{3} \mathrm{CN}\right) \delta 158.95(\mathrm{C}=\mathrm{O}), 67.92(\mathrm{~N}-\mathrm{CH}-\mathrm{N}), 53.83\left(\mathrm{C}\left(\mathrm{CH}_{3}\right)\right), 35.21\left(\mathrm{C}_{2}-\mathrm{CH}_{3}\right)$, $28.34\left(\mathrm{CH}_{3}\right), 11.75\left(\mathrm{CH}_{2}-\mathrm{CH}_{3}\right)$.

3c. 2,6-Dibenzyl-4,8-di-tert-butyl-2,4,6,8-tetraaza[3.3.0]octane-2,7-dione: Yield $83 \%$. $\mathrm{Mp}=223-225^{\circ} \mathrm{C} . \mathbf{I R}, \mathrm{cm}^{-1}: 3062,3028,2968,2934,2892,1704(\mathrm{C}=\mathrm{O}), 1687(\mathrm{C}=\mathrm{O}) .{ }^{1} \mathbf{H}$ NMR $(400$ $\mathrm{MHz}, \mathrm{CD}_{3} \mathrm{CN}$ ) 7.39-7.19 (m, 10H, Ph); 5.43 (s, 2H, N-CH-N), 4.79 ( $\left.J=17.3 \mathrm{~Hz}, \mathrm{~d}, 2 \mathrm{H}, \mathrm{CH}_{2}-\mathrm{Ph}\right), 4.75$ $\left(J=17.3 \mathrm{~Hz}, \mathrm{~d}, 2 \mathrm{H}, \mathrm{CH}_{2}-\mathrm{Ph}\right), 1.30$ (s, 18H, $\left.\mathrm{CH}_{3}\right) .{ }^{13} \mathbf{C} \mathbf{N M R}\left(100 \mathrm{MHz}, \mathrm{CD}_{3} \mathrm{CN}\right) \delta 159.14(\mathrm{C}=\mathrm{O}), 138.11$ (i-Ph), $128.60(m-\mathrm{Ph}), 126.16$ (o,p-Ph), $68.41(\mathrm{~N}-\mathrm{CH}-\mathrm{N}), 54.08\left(\underline{\mathrm{C}}\left(\mathrm{CH}_{3}\right)\right), 43.73\left(\mathrm{CH}_{2}-\mathrm{Ph}\right), 28.27\left(\mathrm{CH}_{3}\right)$.

4a. 2,6-Dimethyl-4,8-diisopropyl-2,4,6,8-tetraza[3.3.0]octane-2,7-dione: Yield 34\%. IR, $\mathrm{cm}^{-1}$ 2976, 2942, 2884,1698 (C=O). ${ }^{1} \mathbf{H}$ NMR (400 MHz, CD $\left.{ }_{3} \mathrm{CN}\right) 5.11(\mathrm{~s}, 2 \mathrm{H}, \mathrm{N}-\mathrm{CH}-\mathrm{N}), 3.77-3.73$ (m, 2H, $\mathrm{CH}), 1.88\left(\mathrm{~s}, 6 \mathrm{H}, \mathrm{CH}_{3}\right), 1.30-1.22\left(\mathrm{~m}, 12 \mathrm{H}, \mathrm{CH}_{3}\right) .{ }^{13} \mathbf{C}$ NMR $\left(100 \mathrm{MHz}, \mathrm{CD}_{2} \mathrm{Cl}_{2}\right) \delta 159.17(\mathrm{C}=\mathrm{O}), 70.78$ (N-CH-N), $46.67(\mathrm{CH}), 20.58\left(\mathrm{CH}_{3}\right), 19.35\left(\mathrm{CH}_{3}\right)$.

4b. 2,6-Diethyl-4,8-diisopropyl-2,4,6,8-tetraaza[3.3.0]octane-2,7-dione: Yield 51\%. IR, $\mathrm{cm}^{-1}: 2974,2937,2881,1693(\mathrm{C}=\mathrm{O}) .{ }^{1} \mathbf{H}$ NMR $\left(400 \mathrm{MHz}, \mathrm{CD}_{3} \mathrm{CN}\right) 5.16(\mathrm{~s}, 2 \mathrm{H}, \mathrm{N}-\mathrm{CH}-\mathrm{N}), 3.69-3.66$ (m, $\left.2 \mathrm{H}, \mathrm{CH}\left(\mathrm{CH}_{3}\right)_{2}\right), 3.51-3.09\left(\mathrm{~m}, 4 \mathrm{H}, \mathrm{CH}_{2}\right), 1.07-1.35\left(18 \mathrm{H}, \mathrm{CH}_{3}\right) .{ }^{13} \mathbf{C} \mathbf{N M R}\left(100 \mathrm{MHz}, \mathrm{CD}_{3} \mathrm{CN}\right) \delta 158.66$ $(\mathrm{C}=\mathrm{O}), 68.16(\mathrm{~N}-\mathrm{CH}-\mathrm{N}), 47.26(\mathrm{CH}), 36.60\left(\mathrm{CH}_{2}\right), 19.63,19.91\left(\mathrm{CH}_{3}\right), 11.97\left(\mathrm{CH}_{3}\right)$.

4c. 2,6-Dibenzyl-4,8-diisopropyl-2,4,6,8-tetraaza[3.3.0]octane-2,7-dione: Yield 58\%. IR, $\mathrm{cm}^{-1}:$ 3320, 3172, 2976, 2934, 2892, $1714(\mathrm{C}=\mathrm{O}), 1688(\mathrm{C}=\mathrm{O}) .{ }^{1} \mathbf{H}$ NMR $\left(400 \mathrm{MHz}, \mathrm{CD}_{3} \mathrm{CN}\right)$ 7.40-7.24 
(m, 10H, Ph); 5.06 (s, 2H, N-CH-N), $4.72\left(J=16.4 \mathrm{~Hz}, \mathrm{~d}, 2 \mathrm{H}, \mathrm{CH}_{2}-\mathrm{Ph}\right), 4.35\left(J=16.4 \mathrm{~Hz}, \mathrm{~d}, 2 \mathrm{H}, \mathrm{CH}_{2}-\right.$ $\mathrm{Ph}), 3.43-3.45$ (m, 2H, CH), $1.22\left(\mathrm{~s}, 12 \mathrm{H}, \mathrm{CH}_{3}\right) .{ }^{13} \mathrm{C}$ NMR (100 MHz, $\left.\mathrm{CD}_{3} \mathrm{CN}\right) \delta 158.94(\mathrm{C}=\mathrm{O}), 137.69$ (i-Ph), 128.60 (m-Ph), 127.19 (o,p-Ph), $69.29(\mathrm{~N}-\mathrm{CH}-\mathrm{N}), 48.05(\underline{\mathrm{CH}}), 45.55\left(\mathrm{CH}_{2}-\mathrm{Ph}\right), 19.46\left(\mathrm{CH}_{3}\right)$.

\section{Results and discussion}

The starting disubstituted glycolurils were prepared by cyclization of monosubstituted urea with glyoxal by the reported procedure [11]. The general protocol for the study is illustrated in Fig. 1.

Figures 2-4 show the product yield plotted against the reaction temperature and time and molar ratio of starting components by the example of the synthesis of dibenzyl-di-tertbutylglycoluril.

As is seen in Fig. 2, the target product yield at $25{ }^{\circ} \mathrm{C}$ and $35{ }^{\circ} \mathrm{C}$ was as low as 9 and $21 \%$, respectively, whereas the temperature rise to $45^{\circ} \mathrm{C}$ resulted in a threefold increase in the yield. The maximum yield of dibenzyl-di-tert-butylglycoluril of $83 \%$ calculated as di-tert-butylglycoluril was achieved when the reaction temperature was $75{ }^{\circ} \mathrm{C}$, which is close to the solvent boiling point.

\begin{tabular}{|l|l|l|}
\hline $\mathbf{N o}$ & $\mathrm{R}_{1}$ & $\mathrm{R}_{2}$ \\
\hline $\mathbf{3 a}$ & ${\mathrm{C}\left(\mathrm{CH}_{3}\right)_{3}}_{3}-\mathbf{4 c}$ \\
\hline $\mathbf{3 b}$ & $\mathrm{C}\left(\mathrm{CH}_{3}\right)_{3}$ & $\mathrm{CH}_{3}$ \\
\hline $\mathbf{3 c}$ & $\mathrm{C}\left(\mathrm{CH}_{3}\right)_{3}$ & $\mathrm{Bn}$ \\
\hline $\mathbf{4 a}$ & $\mathrm{CH}\left(\mathrm{CH}_{3}\right)_{2}$ & $\mathrm{CH}_{3}$ \\
\hline $\mathbf{4 b}$ & $\mathrm{CH}\left(\mathrm{CH}_{3}\right)_{2}$ & $\mathrm{C}_{2} \mathrm{H}_{5}$ \\
\hline $\mathbf{4 c}$ & $\mathrm{CH}\left(\mathrm{CH}_{3}\right)_{2}$ & $\mathrm{Bn}$ \\
\hline
\end{tabular}

Fig. 1. General scheme for the study of the N-alkylation reaction of disubstituted glycolurils

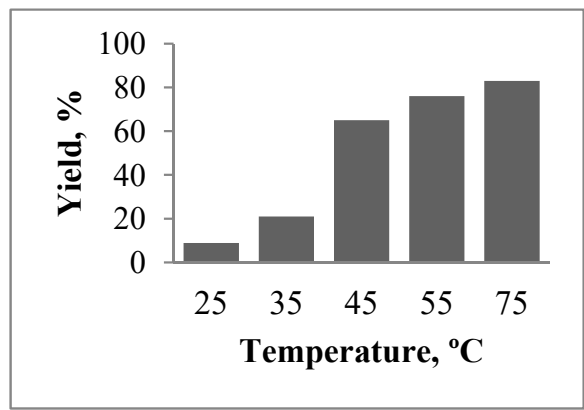

Fig. 2. Yield of $\mathbf{3 c}$ plotted against reaction temperature 


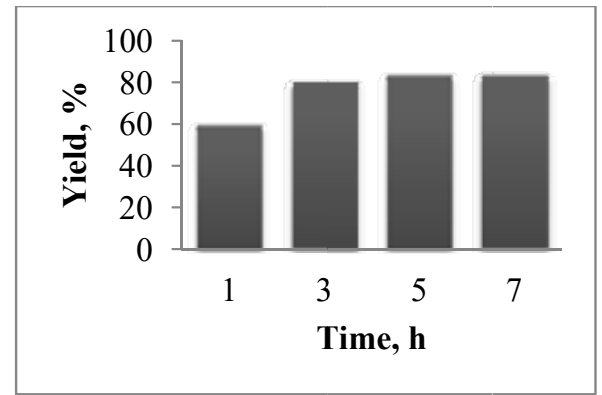

Fig. 3. Yield of $\mathbf{3 c}$ plotted against reaction time

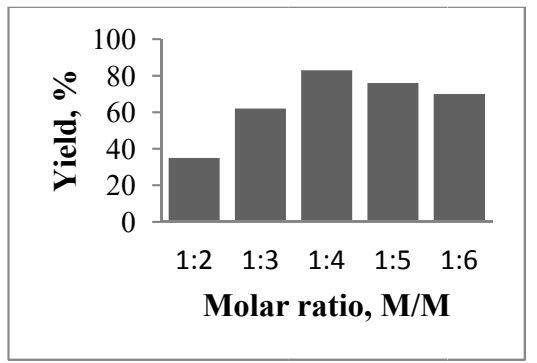

Fig. 4. Yield of $\mathbf{3 c}$ plotted against molar ratio of di-tert-butylglycoluril to benzyl chloride

The reaction time increment from 1 to $3 \mathrm{~h}$ sharply enhanced the product yield (Fig. 3), and the further rise in reaction time almost did not favor an increase in the target product yield. Thus, the holding time of $3 \mathrm{~h}$ was more appropriate.

The experimental results demonstrated that the 1:4 M/M molar ratio of di-tert-butylglycoluril to benzyl chloride was optimum. It is seen in Fig. 4 that the product yield declined as the alkylating agent concentration in the initial mixture was raised to 1:6 M/M. It was also found that benzyl chloride should be used as the alkylating agent because it gave a higher yield of the target product than benzyl bromide, and its application is more preferable owing to its lower toxicity and greater availability compared to benzyl bromide.

It can be inferred from the aforesaid that the following conditions are required for the maximum yield of dibenzyl-di-tert-butylglycoluril: 1:4 molar ratio of the reactants, temperature $75{ }^{\circ} \mathrm{C}$ and time $3 \mathrm{~h}$. In this case, the target product yield was $83 \%$.

\section{Conclusions}

Never-before-seen glycoluril tetraderivatives were synthesized herein and dimethyl-di-tertbutylglycoluril was derived by the new method. High-yielding conditions were determined by the example of dibenzyl-di-tert-butylglycoluril: 1:4 M/M molar ratio of di-tert-butylglycoluril to benzyl chloride, temperature $75^{\circ} \mathrm{C}$ and time $3 \mathrm{~h}$.

\section{Acknowledgements / Благодарности}

The reported study was funded by RFBR, project number 19-33-90060.

$$
-44-
$$


Исследование выполнено при финансовой поддержке РФФИ в рамках научного проекта № 19-33-90060.

\section{References / Список литературы}

1. Lenev D.A, Lyssenko K.A., Kostyanovsky R.G. The chiral drug Albicar: resolution of its racemate via complexation with BINOL. New J. Chem. 2010. Vol. 34, P. 403-404.

2. Kravchenko A.N., Baranov V.V., Gazieva G.A. Synthesis of glycolurils and their analogues. J. Russ. Chem. Rev. 2018. Vol. 87, P. 89-108.

3.Kravchenko A.N., Baranov V.V., AnikinaL.V., Vikharev Yu.B., Bushmarinov I.S., Nelyubina Yu.V. Neuroprotective activity of (+)-(S)-2-[(1S,5R)-(3,7-dioxo-2,4,6,8- tetraazabicyclo[3.3.0]oct-2-yl)]-4methylthiobutanoic acid. Russian Journal of Bioorganic Chemistry. 2012. Vol. 38(5), P. 550-557.

4. Baranov V.V., Antonova M.A., Nelyubina Yu.V., Kolotyrkina N.G., Kravchenko A.N. New Method for the Synthesis of 1-Substituted (3a,6a)-Diarylglycolurils. Synlett. 2017. Vol. 28, P. 669-672.

5. Baranov V.V., Antonova M.A., Nelyubina Yu.V., Kolotyrkina N.G., Zanin I.E., Kravchenko A.N., Makhova N.N. Regioselective synthesis of 2,8-disubstituted 1,5-diphenylglycolurils. Mendeleev Commun. 2014. Vol. 24, P. 173-175.

6. Kravchenko A.N., Sigachev A.S., Maksareva E.Y., Gazieva G.A., Trunova N.S., Lozhkin B.V., Pivina T.S., Il'in M.M., Lyssenko K.A., Nelyubina Y.V., Davankov V.A., Lebedev O.V., Makhova N.N., Tartakovsky V.A. Synthesis of new chiral mono-, di-, tri-, and tetralglycolurils. J. Russ. Chem. Bull. 2005. Vol. 54 (3), P. 691-704.

7. Micheletti G., Delpivo C., Baccolini G. A green synthesis of glycoluril derivatives in aqueous solution with recycle of the waste. Green Chem. Lett. Rev. 2013. Vol. 6 (2), P. 135-139.

8. Anikina L.V., Vikharev Yu.B., Baranov V.V., Malyshev O.R., Kravchenko A.N. Preparative synthesis and pharmacological activity of Albicar racemate and enantiomers. Mendeleev Commun. 2018. Vol. 28, P. 317-319.

9. Boileau J., Wimmer E., Carail M., Gallo R. Preparation of nitro and nitroacetyl derivatives of glycouril. Bulletin de la Societe Chimique de France. 1986. Vol. 3, P. 465-469.

10. Boileau J., Carail M., Gallo R., Pierrot M. Acetylated nitro derivatives of glycoluril. Prop. Exp. Pyr. 1985. Vol. 10 (4), Р. 118-120.

11. Ильясов С.Г., Чикина М.В. Исследование взаимодействия моноалкилмочевин с глиоксалем и нитрование продуктов их конденсации. Ползуновский вестник. 2009. Т. 3. С. 1113. [Ilyasov S.G., Chikina M.V. Investigation of the interaction of monoalkylureas with glyoxal and nitration of their condensation products. Polzunovskiy Vestnik. 2009. Vol. 3, P. 11-13. (In Russ.)] 